\title{
Brushing with Organized Crime and Democracy: The Art of Making Do in South Asia ASHRAF HOQUE and LUCIA MICHELUTTI
}

This article explores the performances of a particular category of young men often derogatively referred to as "chamchas" (sycophants) who are using the art of making do (jugaad) by exploiting and bluffing links with powerful political networks and political parties, as well as friendships with strongmen and their criminal crews. Crucially, the comparative ethnography across India (western Uttar Pradesh) and Bangladesh (Sylhet) introduces readers to the "contact zone" where legality, semi-legality, and organized criminal systems meet. In so doing, the article unravels the working of the democratically elected "Mafia Raj."

Lucia Michelutti (1.michelutti@ucl.ac.uk) is Professor of Anthropology at University College London.

Ashraf Hoque (a.hoque@ucl.ac.uk) is Teaching Fellow at University College London.

\section{INTRODUCTION}

"You need jugad in this world to get rich ... and the only way one can get rich fast is to get into politics" (Rakesh, twenty-six years old, aspiring leader or chamcha, western Uttar Pradesh, North India). 
"A good politician is the one who can think fast and make things happen faster" (migrant laborer, twenty-three years old, Sylhet, Bangladesh).

This article explores "the art of making do" (jugaad) and the game of democracy across North India and Bangladesh. It does so by investigating the performances of a particular category of "jugaadis" (improvisers) sometimes derogatively referred to as "lanjoo panjoo" (leader in the making) or "chamchas" (sycophants) in their local areas. ${ }^{1}$ The exploration of their career trajectories not only constitutes a fruitful field for anthropologically studying how the democratic game is used to stage a better life, but also sheds light on the working of systems of (criminal) democratic power-locally known by such vernacular terms as "Goonda Raj" or "Mafia Raj" in North India, and "Manstanocracy" in Bangladesh, that is, mafia or criminal rule. ${ }^{2}$ These are hybrid systems of governance where criminal organizations, politicians, police, and bureaucrats are entangled in a relationship of collusion and divestment, sharing control over spaces and population (cf. Jaffe 2013). This article shows how six young men attempt to enter such structured, economic and political, muscular systems of governance. Central to their career path is the ability to master how to enforce.

In a seminal book, van Schendel and Abraham (2005) discuss the thresholds between large-scale organized crime, micro-level organized crime, and informal economy. It should be noted that these complex "worlds in between" have not been explored and theorized in the context of South Asia. In the region, historians and social anthropologists have commonly focused on informality and/or on studying colonial notions of "thuggery," "the dacoit," and "the criminal tribe or caste." The latter widely explore the conditions under which a distinctly modern notion of crime took shape in colonial South Asia. ${ }^{3}$ Yet, the thresholds between criminal politics, 
organized crime, and gangs have not received equal scrutiny (Sen 2007). Our ethnographic exploration focuses on these 'contact zones' and responds to recent calls for an anthropology of modern statehood (Das and Poole 2004; Hansen and Stepputat 2005; Spencer 2007) in its relationship to violence, corruption, and crime (Briquet and Favarel-Garrigues 2010; Comaroff and Comaroff 2016; Parnell and Kane 2003; Schneider and Schneider 2008). We are also in dialogue with classical South Asian debates on patronage, caste, and ethnic politics (Chandra 2004; Jaffrelot 2002). A great deal of work on clientelism and patronage in South Asia tends to overemphasize how leaders mediate or distribute resources rather than their role as violent protectors and enforcers (see, e.g., Piviliasky 2014). In a similar vein, South Asian "patronage democracies" (Chandra 2004) have been conceived as democracies in which elected political leaders have the power to distribute the vast resources controlled by the state to vote on an individual basis. In a "Mafia Raj," however, what is crucial is not redistribution but criminal partnerships between the state and private capitalism based on the power of enforcement by force and intimidation. And it is precisely the role of enforcement that we wish to explore in the following discussion and with it the thresholds between the informal economy and organized crime-between "jugaad" and violent political entrepreneurship.

\section{“The ARt Of Making Do" AND Politics}

India and Bangladesh offer a particularly useful comparative context for understanding such micro power dynamics. Since 1947, the political environments of the two countries, which share a great deal of historical, cultural, and political continuity, have diverged. The emergence of democracy in India, "authoritarianism" in Pakistan, and what has been termed "confrontational democracy" in Bangladesh has produced at times distinctive political 
trajectories, patterns of political participation, styles of leadership, and conceptions of justice (Jalal 1995). However, by contrasting ethnographies of jugad and democratically elected systems of "Mafia Raj," our study highlights fascinating parallels in the ways criminal entrepreneurship and violence intertwine with statehood today in the region and beyond it. Indeed, scholarly works on South Asia tend to be generally "India-centered" or focus on specific in-country issues. The result is that common "South Asian" practices and the effects of more globalized trends often remain unexamined and untheorized (cf. Harper and Amrith 2012). Thinking broadly and cross-culturally about the nature of (criminal) power and politics allows us to challenge essentializations of "Indian" or "Bangladeshi" ideas and practices of power as rooted, for example, in established Hindu or Muslim sociocultural registers of power and authority. Importantly it helps to us to identify a set of situations and interlocked logics of profit, power, and personal sovereignties that are highly comparable with other places where crime and politics have over time been thoroughly intertwined: for example, Italy, Russia, the Philippines, Mexico, Japan, and the United States. ${ }^{4}$

What are the parallels? For a start, in both our settings in western Uttar Pradesh and Sylhet "the art of making do" is often referred to with the same term, jugaad, which means to improvise, to be resourceful and entrepreneurial. It can also refer to various sorts of improvised machines and makeshift structures, quick-fix solutions, or workarounds. However, broadly the term implies that one is devising strategies that are not "on books, intended to address practical problems and cope, with a lack of resources, burdensome rules and regulations, inadequate infrastructure and unreliable services" (Chattaraj 2018). Jeffrey, Jeffery, and Jeffery $(2008,5)$ 
have shown how young, unemployed males (jugaadis) live in a highly competitive world in which source, force, and the need to improvise become paramount concerns. In short, jugaad is often conceived as a resourceful way of getting by, as a virtuous practice. By the same token, it is also viewed as a corrupted and criminal practice (cf. Jauregui 2014). Across South Asia, there is a wealth of literature on fixers, brokers, and their vernacular cultures of entrepreneurship, some of which are also linked in interesting ways to "neoliberal discourses." In the 2000s, the Indian government also began to use the term jugaad as a means of advertising a type of homegrown spirit of ingenuity in India. What remains systematically kept in the background is that these often glorified, "neoliberal," informal jobs require enforcement and participation in organized "power syndicates" and "groups" in order to operate. Jugaadis often brush with crime and in order to succeed they need to become enforcers (dabang, mastan).

It should be noted that the art of making do and its capacity to legitimize (or reject) corruption and criminality is certainly not specific to South Asia. Similar "arts" have been documented at length in South Italy (Pardo 1996; Pine 2012), to tease out the relation between organized forms of crime (like Camorra in Naples), or in the context of Africa, to analyze the figure of the trickster (Bayart et al. 1999; Simone 2004). Comparatively, however, one of the peculiar features of the landscape of ideas and practices in "the art of making do" in North India and Bangladesh is the use of politics as a system for upward mobility and the acquisition of personal power and wealth across all social classes and the caste or communities spectrum. This is what people refer to as "political" jugaad. This article focuses on political "jugaadis" and on the jugaad that emerging leaders need to master in order to start and establish a career in the Uttar Pradesh "Mafia Raj" and the Sylhet "Mastanocracy." 
South Asia is quite well known for its high levels of voter turnout. What is less known is that citizens in both India and Bangladesh also contest elections in extraordinarily large numbers. The market of politics provides economic and symbolic resources that are creatively used to expand personal assets and renegotiate individual and communities' lives (Michelutti 2008, chap. 7). It has been suggested that democracy has survived and flourished in India because it was quickly seen to be one of the most effective systems to achieve "personal sovereignty" (cf. Varma 2004, 7). Similarly, in Bangladesh, the revolution of 1971 created a socioeconomic power vacuum caused by the demise of the old political elite, which, in turn, was appropriated by newly urbanized, aspirational working and lower middle classes (Van Schendel 2009, 251-52) who engage with the market of politics to convert new money into status and power (and more money). Thus, not surprisingly, our fieldworks produced a common substantial finding. In both settings, the figure of the strongman politician is a glamorous and coveted one. This is true not only for working-class and poor, unemployed youth who aspire to become self-made criminalstrongman-fixers and politicians but also for wealthy men and women and established middleage businessmen or mafia-dons who aspire to be voted as MLAs or MPs. ${ }^{5}$

$$
* * *
$$

The assertions and hyper politicization of our informants' lives and the role of democracy in shaping the local manifestations of arts of making do make sense when one explores the "palimpsest of sovereignties" (Comaroff and Comaroff 2006, 9) that features in South Asian political landscapes. In postcolonial South Asia, "authority" is hyper fragmented (Hansen and Stepputat 2005). The legacy of a segmented society reflects itself in processes of "vernacularisation of democracy" (Michelutti 2008) that are producing ad hoc ideas and practices of democracy across communities and castes (see also Witsoe 2009). In this socially 
and politically segmented environment, competing leaders often present themselves as having the capacity "to get things done" for their castes, clans, brotherhoods, and village communities in ways that sidestep the law (Michelutti 2010, 46). It follows that localized "Mafia Raj" regimes are often presided over by self-made men (and seldom women) who attempt to achieve monopolistic control over an area's coercive and economic resources. It is in this context that everybody wants to (and in theory can) become a "raja" (king or monarch). As Brijesh Yadav (successful local neighborhood strongman, forty-two years old, western Uttar Pradesh) puts it: "Today muscle is power. Earlier, only the son of the king could rule. Today everybody can rule. You need weapons to rule. Leaders need to have guns. Not everybody should have guns-only people with status. However, nowadays everyone who wishes can get guns and rule." The stories of our six young men show that while on the one hand everybody wants to (and in theory can) become a strongman or raja, this is often untenable in practice. "The art of making do" is indeed not less structured than any other social phenomena. The next section sketches the backgrounds against which the jugaadis of this article perform "the art of making do" in an attempt to become political bosses with personal power and economic wealth.

\section{Background: Western Uttar Pradesh and Sylhet and Their Criminal Political}

\section{ECONOMIES}

Systems of "Mafia Raj" develop where there is wealth and where the state is too compromised to regulate the conflicts and opportunities that arise from such wealth. This is clearly shown in the comparative material on Russia, Italy, East Asia, and Africa (for a summary of this literature, see Volkov 2002). The provincial town in western Uttar Pradesh where fieldwork was conducted has undergone tremendous economic changes over the past two 
decades. The area is witnessing a construction boom and skyrocketing real estate prices as a result of quicker access to Delhi thanks to the construction of the Yamuna Expressway, and to its proximity to the industrial and residential hubs of Noida and Faridabad. Here a predatory and criminalized economy finances political parties and the political careers of gangsters (Martin and Michelutti 2017; Vaishnav 2017). In the district, multi-party competition correlates with higher levels of communal and caste-based conflict (Wilkinson 2004), and a higher number of criminal political candidates. Democratic competition, as Wilkinson has argued, produced a heightened scramble for monetary and political resources and turned money and muscle-power into prerequisites for electoral success.

In Sylhet - the Bangladesh province where the overwhelming majority of BritishBangladeshis originate-fieldwork was conducted in a village and district with a prosperous remittance economy. Here, during the fifteen years of democracy leading up to the quasi-military coup in January 2007, it was the confrontational nature of political competition (particularly between the two main political parties) and economic liberalization that created a widespread need for extra-legal economic and muscle resources. Both our case studies show how systems of "Mafia Raj” encapsulate the hybridization of state and crime (Bayart et al. 1999). Expanding systems of "Mafia Raj," as Harriss-White $(2003,7)$ shows in the context of South Asia, "increasingly serves private accumulation: a nexus in which politicians, officials, criminals, and businessmen and their (often poor and dependent) "runners" and fixers are bound together in a mutually protective embrace." Enforcement with impunity and trading or imposing protection is the central trope of such il/legal political economies (see Martin and Michelutti 2017; Michelutti et al., forthcoming). Thus these systems take "the art of making do" to a whole new level, and one not considered in any detail in the literature on entrepreneurs in South Asia, but widely explored in 
the work on violent cultures of entrepreneurship in other settings. This is jugad but on a different scale, in a different sphere, and with different consequences, often as serious as life or death. Let us explain.

It is widely documented that leaders in South Asia (together with fixers and political brokers) spend a great deal of time resolving problems for their supporters and mediate between them and the state (Berenschot 2011; Birtchnell 2011; Manor 2000; Reddy and Haragopal 1985) and in ensuring the delivery of services (Anand 2015). However, this literature does not completely shed light on the many instances in which people approach leaders not in pursuit of a license, or a birth certificate, or an electricity connection, but to use their powers to keep those bureaucrats, fixers, and other politicians who demand too much money for their (illicit) services — or who do not deliver after being paid—in place.

For example, in western Uttar Pradesh, one of the most common requests one hears at darbars is to keep in check police personnel who overcharge for fraudulent First Information Report entries or the annulment of cases. ${ }^{6}$ Another common request in both western Uttar Pradesh and Sylhet is for assistance in getting people out of prison or to keep them out of prison. It follows that money, threats, and intimidation need to be at hand to put pressure on people to get things done, from everyday bureaucratic procedures, such as registering land, issuing birth certificates, or settling disputes, to assistance with the police, and even getting out of jail. Crucially, the services "getting done" are often clearly illegal. Citizens need to continuously break or bend the law (do jugaad) to get along with life. Similar to the ways mafia networks in other parts of the world operate (Gambetta 1993; Sidel 2004; Volkov 2002), powerful leaders protect people involved in both legal and illegal activities; a practice interchangeably referred to as "sewa" (social work) or "goondagardi" (criminal work). Any efficient and authoritative boss, 
therefore, must be able to demonstrate aptitude in these "enforcing" or "protection" tasks. On the whole, this material shifts the attention from individual political mediation, the capacity to access to state resources, and the provision of alternative resources (Berenschot 2011) to the capacity (real or perceived) to enforce orders "to get things done" with impunity. But how does one acquire such capacity?

\section{THE POWER OF MONEY AND ForCE}

In the context of Bangladesh (but increasingly so in North India), one must get rich. Money is what increasingly provides enforcement power. Bangladeshis, particularly in rural Sylhet, do not trust poor leaders. If a politician is rich, it means he possesses "power" (komota, shakti, taqat). He or she is aware of how to make money (often from criminal entrepreneurship), how to spend it, and, most importantly, how to keep it. Money, in Bangladesh, equates to enforcement and a web of influential and efficacious contacts that, in turn, buy impunity. Similarly, in India, as one MLA in western Uttar Pradesh explained: “people expect politicians to be not modest but to show off their wealth and power-otherwise you do not get respect."

Next, the aspirant boss (elected or not elected) is expected to be wily (chalak, hoshyar, buddi-maan). He or she needs to have scheming skills. In a competitive world, he or she needs to possess the appropriate guile and acumen to protect and enforce his or her followers' interests. In both studied settings, to belong to a political family, formal education, and "being smart" may be demonstrative of these attributes, but not always. In Bangladesh, it is crucial that a leader is able to speak well in public (shundor maat-kota). Stammering, hesitating, or a lack of passion in a public forum will undoubtedly provoke a delegitimizing and potentially career-ending backlash in the form of ridicule and repulsion (Ruud 2001). In Western Uttar Pradesh, "speaking well" is a 
plus but, by the same token, not being a good orator and not being educated does not prevent many violent entrepreneurs from translating their enforcement skills into formal positions of power. Similarly, in Bangladesh, speaking well in public does not work if one lacks the nous or single-mindedness to push an agenda in an aggressive environment.

In this regard, a direct background in "enforcement" and involvement in broader criminal networks is good for the resume. Alternatively, close collaboration with reputable goons and mafia-dons is essential. A mastaan or dabang is conditioned by the mores of the "street"; he or she is aware of his or her detractors and even more aware of how to push them out of the way. In places like western Uttar Pradesh, where security is increasingly available only when your own leader is in power, "democratic rajas" (Michelutti 2014a) must not only be generous benefactors and speak well, but also protect their "people"—defending and punishing — as the need may arise. This thinking finds expression in the widespread idioms of fearlessness and virility that surround political life and the popular imagery that advertises politicians' "heroic" (bahadur) capacity to protect. So, violent protectors need to win their supporters using violence, not only to threaten and subordinate them (although they use it for those purposes too), but also as a form of guarantee of their capacity to rule-something their supporters increasingly demand. Thus supporters not only expect that their representatives will help them get jobs and access to health provisions, resolve their disputes, arrange marriages, and so on, but they also want to be assured that their leaders have "safeguards" in place that guarantee that their promises will materialize. They want enforcing representatives.

\section{CASTe ANd COMMUnity BACKGROUND}


It should be emphasized that, in the context of Uttar Pradesh, most of the qualities described above work more efficiently if one is a member of the right caste or community. This means to belong to one of the local dominant and/or numerically strong castes. In this region bosses' capacity to dominate particular territories is often linked to caste and community forms of territorial governance. "Territorial” forms of democracy, as Witsoe (2009) conceptualized, go hand to hand with contemporary Mafia-esque bosses in western Uttar Pradesh. As Bangladesh is a Muslim-majority country, large-scale caste mobilization is much less pronounced than in neighboring India. Having said this, some prominent caste groups exercise significant influence in democratic processes (fishing castes, for example). Nevertheless, caste politics remains subsidiary to the interests of class groups, such as peasants (krishok) and workers (sromik), that are highly unionized and consolidated within the Bangladeshi political landscape. On the other end of the scale, traditional landowning groups (zamindar, talukdar), and members of the colonial (Chauduri) or Mughal (Ashraf) ruling class have been steadily conceding political ground since independence. Whereas once the political class was dominated by these elites, the terrain has shifted at an accelerated rate, particularly since the restoration of democracy in 1991, which ushered in the era of economic liberalization. Currently, given politicians' social backgrounds are secondary to their abilities as "leaders." And ideal leaders are perceived most often as those who, through their wealth and popularity, are best able to provide "services" and "security" for their constituents, regardless of their socioeconomic background.

Thus in terms of caste and status, while social background and hierarchical structures still shape “Mafia Raj” regimes, increasingly today's strongmen have a diverse sociological background. We will show that this is a world where the personality of the bosses is becoming particularly important precisely because their power is often detached from hereditary status and 
patterns of local caste or community sovereignties. It follows that in our settings what becomes a source of conversation and admiration is often personal individual achievements rather than heritage. In the next sections of the article, we illustrate some of these dynamics at work by introducing readers to six political jugadis and enforcers at different stages of their careers.

We start with the stories of Ahmed and Tufayl in Bangladesh and Ravi Kumar and Shiv Singh in North India. The Bangladeshi aspiring bosses are in their mid-twenties, unemployed, and from wealthy Londoni families. ${ }^{7}$ Apart from their family's wealth, the two do not have much going for them in the sphere of political (criminal) prowess. They lack education, personal charm, the ability to speak in public, and menace. The North Indian aspirants are in their midtwenties and thirties, too. The first is a party worker, but he describes himself as a youth leader. He is a sycophant of the local strongman and he aspires to go independent and to contest ward elections in two years, and to contest in the MLA elections in 2022, but he does not belong to the right caste and does not have the muscle to move up the career bosses' ladder. The second is an aspiring political boss who is improvising an extortionist career by using the criminal credentials of the local political party. However, he does not have the "guts" to use violence and does not have the contacts (and membership) in the local oil mafia that would enable him to advance professionally in the local "Mafia Raj" system.

In the process of relating these stories, we hope to be able to illustrate how their spirit of improvisation appeals (or not) to Bangladeshi and Indian followers, and how these seemingly lowly aspiring bosses manage, with varying degrees of success, to manipulate (particularly poor) locals into believing in their value. Finally, these accounts will be contrasted with two young self-made enforcers (dabang, mastan) in an effort to ethnographically draw out the role of 
enforcement (and jugad as criminal entrepreneurship) in shaping criminal political economies in South Asia.

\section{THE STORIES OF FOUR "JUGAADIS"}

\section{Ahmed (Sylhet)}

The Union Parishad chairman lived next door to our homestead. Sometimes we would sit on the edge of the pond neighboring the chairman's personal longhouse watching men from all over the union come in and out. A permanent feature of this landscape was Ahmed. In between loitering, minding the family goats grazing in the fields, and prayers, Ahmed engages in political campaigning. Without fail, Ahmed approaches every one of the chairman's visitors and has a conversation with them. Observing from a distance, he tends to retain the attention of those from the lower castes. Higher social groups are inclined to ignore him and pass by or, especially younger (wealthy) men, tease and poke fun at him. On one occasion, we spoke to a fisherman who had just been to see the chairman and, as usual, Ahmed approached him on the way into the homestead. We asked the man why he had visited the chairman. It turned out that his roof had collapsed in the storms the previous night. It was customary among the village poor to seek community support in such circumstances, and the chairman was the first port of call. The chairman promised the man that he would do what he could to support him, and that he would ask various Londoni households in the area to contribute funds for the repair. We then asked what Ahmed spoke to him about. He told us that Ahmed tried to find out why he was visiting the chairman. When he discovered that it was because of a collapsed roof, Ahmed told the man that he had many friends who were in the construction business and that the situation would be solved within the week if the man so wished. He also said that the chairman was busy and did 
not have time to deal with petty requests. He claimed to have contacts in London who would send money for the repair. The man refused: "How can I wait that long, Baba? There will be no house in a week!"

After speaking to a few of our interlocutors, we learned that Ahmed offered his "services" to villagers in the hope of being recognized as a canny operator and "fixer." Some of the more unassuming ones would take up his offer, only to be ultimately disappointed. In actuality, he had no contacts and no money but relied on the chairman's networks. Some poor villagers would assume that Ahmed is one of the chairman's associates, given his social stature and proximity to the latter, and accept his advice. Ahmed would then approach the chairman himself and inform him of the issues raised by a given villager. The case would eventually be concluded, depending on its feasibility, but would take much longer than if the villagers actually went directly to the chairman. Most people in the village, however, know that Ahmed is a bluff artist and dismiss his advances.

\section{Tufayl}

Tufayl is a member of the richest lineage group (gushti) in the village. His paternal uncles (once removed) own a chain of successful Indian restaurants in the English Midlands. They regularly send remittances to their extended family in the village. Tufayl's nuclear family, like Ahmed's, receives a portion of the money that then subsidizes revenues generated from sharecropping. Despite these means of income, Tufayl's immediate family is considerably less wealthy than the other households in the lineage group. His father has been ill for many years and hence unable to work. His oldest brother is a work visa over-stayer in the United Kingdom, and has not sent any money back for a few years. His other brother is in prison on murder 
charges. Tufayl is now the only male sibling in his home, and expectations for him to provide for his family are high.

Unlike Ahmed, Tufayl went to secular school. Like Ahmed, he never quite matriculated. Tufayl has never secured a job either. He spends most of his days loitering around the center of the village - in the tea stalls, on the bridge, on the phone. He is into fashion. He wears the latest designs and has extremely ostentatious tastes. His favorite combination seems to be a bright pink and lime green checkered shirt with mustard corduroy trousers. He wears this combination as often as possible, including at panchayat meetings, village functions, and weddings. Tufayl is also into local politics and harbors ambitions of becoming a politician. As his lineage group is one of the most influential in the village, Tufayl has recognized an opportune shoe-in into the political scene. In addition, some of his cousins are prominent members of the mainstream political party's youth wings in the union, which he feels adds to his credibility. But Tufayl is not a politician in any regard. He speaks too fast, is very short and very slender, and has a penchant for saying the wrong thing at the wrong time.

Despite these obvious shortfalls, Tufayl has cultivated a reputation among impoverished, low-caste groups as someone to turn to when in need of "help" (shahajjo).

AH: You always seem to be offering tea to Tufayl [at the stall], why? Villager: He is someone who can help us. His uncles are very rich. They always come from London with money to share. Maybe he can speak (sifarish) to them on my behalf. I have four young daughters and they are all unmarried. The tea stall is not enough. Weddings are expensive.

AH: Do you know of anyone Tufayl has helped in the past? 
Villager: Last year when his eldest uncle came, they sacrificed fifty cows for the poor. I went to the madrasa to get my household's share and found Tufayl there handing out portions. I asked him for some extra and he gave me two bags of biryani. My children were so pleased! He could only do that because he's the nephew. Like that, if you stay close to him, he will help you.

It is this optimism and sense of expectation among some of the villagers that Tufayl capitalizes upon. In this part of Bangladesh, being connected to a Londoni lineage group has the potential to provide many rewards. Those without Londoni links are by far the most socioeconomically desolate in the region (Gardner 1995). Londonis, when they return, are expected to be generous and altruistic with their money and resources. They provide a form of $d e$ facto welfare safety net for poor villagers. When Londonis cannot be contacted or approached directly, those of their relatives who are resident in Bangladesh are approached as intermediaries in the granting of donations. Moreover, over the past two decades, more and more Londoni lineage groups have entered formal politics as a means to manage their property and business interests in Bangladesh (Garbin 2002). As a consequence, many Londoni lineage groups have risen to powerful positions at union and sub-district levels. Some have even forged business links with high-ranking politicians at the national level. These developments do not go unnoticed. Villagers are acutely aware of the potential riches and influence that a Londoni patron can offer. And so is Tufayl. Even though his own family is struggling to survive, he is aware of the wider perceptions towards his lineage group, and he spends most of his time playing up to them. By far his most favorite public performance involves his mobile phone. Most afternoons, Tufayl can be found sitting on the side of the road that connects the paddy fields to the village center. As 
workers pass by on the way home from the fields, Tufayl can be heard engrossed in political discussions. These conversations are heavily laced with talk of "funds," "donations," and “projects.” Passers-by are clearly impressed.

But, not everyone is impressed. Among the rich farming households, Tufayl is perceived to be a comedy character and, like Ahmed, not taken seriously at all —including by his own first cousin:

Tufayl? He's a fool. He spends all day speaking to a prostitute that he's in love with and makes out he's talking to the mayor of London! He wants to show all these ghulams [tenant group, lit. "slaves"] that he is the real deal and they obviously fall for it- - for a while. Then, when push comes to shove, he doesn't deliver anything. He shames himself and the rest of us. But they [the tenant group] still follow him around because they're as shameless as him! He has nothing. No money, no power. But those workers think he holds the winning lottery ticket. That's why they [the workers] are where they are.

Tufayl has been loitering around the village since he left school ten years ago. In that time, he has not progressed along the political ladder. Tufayl cannot influence village decisionmaking in any way. His only option, it seems, is to garner a following among the village subaltern groups in the hope of being of some assistance to the bigwigs during election time. He and Ahmed are not, however, the only unemployed village youth engaged in "timepass" in this way (Jeffrey 2010). Nor are they the only ones seeking a career in local politics. Ahmed and Tufayl are part of an entire generation of village youth who aspire to become politicians. Some, as we have seen, do not quite make the grade. Others go all the way to the top. 


\section{Ravi Kumar (western Uttar Pradesh)}

Ravi is thirty-three years old. He comes from a middle-class family. His father is a lowerrank bureaucrat, and so is his brother. He used to work in a local computer shop as an assistant. He decided to drop his job when the Samajwadi Party (SP) rose to power in March 2012. Since then he has been one of the many "boys who are nobody but aspire to be somebody" who surround local powerful figures. People derogatorily call them "chamchas" (sycophants), but they call themselves "youth leaders." As the secretary of the local MLA pointed out, "You will find no party workers here, they are all leaders!’ Ravi started to dress up in the white kurta pyjama, which makes "politicians" stand out from the others (the common people) in any Uttar Pradesh provincial town. The "politician uniform" is hence an essential prop in any credible theatrics of power in this part of the world. Ravi said that he believed that a neta (a leader) should be notably dressed in order to have authority. We asked him why he does not wear dark shades like the other "chamchas" that surround Guddu Bhaia (his boss). He said that he is doing "sewa" not "goondagardi." The dark glassed — he said is a signal—a dabang signal— and he also said that Bhaia (and here he was referring to the CM Akhilesh Yadav) "had exhorted the SP youth not to wear them during the last election campaign. I am following his lead.”

In front of Ravi's house, there is a board with his name and the Samajwadi Party's logo, and he arranged his front room to meet "the people." However, he spends most of his time at the residence of his boss to assist with the darbar there and indeed mainly helps out by repairing the office computer. His main daily activities are to be seen close to authoritative people and to get to know them. He also needs to show courage, reliability, and devotion for his boss. Ravi is indeed very devoted to Gudduji (one of the local strongmen or dabang). He aspires to have his 
support in the next municipality elections: "I have it all planned. I am building up a database in which I inserted all the people who I met at Guddu Bhaia's office and the people of my neighborhood who approached me for help. It is all in an Excel document. A database! When I reach 5,000 people I will show it to Guddu Bhaia. This will be a tangible proof of the support that I can bring to the party. This will pave the way for my career with the SP.”

A couple of days after this conversation, we were speaking with Arjun Kumar (a wellestablished businessman in his forties with companies in Delhi, Canada, and the United States). Arjun is indeed a very successful, local, self-made man. We were in the bazaar when Ravi approached. He touched Arjun's feet very ceremoniously, pretending to give respect, but without really meaning it. It turned out that Arjun was Ravi's former employer before he left the Uttar Pradesh provinces to set up his company in the United States five years previously. They exchanged greetings. With an air of importance, Ravi took out his business card with the SP logo and explained to Arjun that he was now one of the local secretaries of the party (there are about eighteen party secretaries in town). He added: "If you need any help, please do contact me." He also told him very pompously that he was planning to contest the Lok Sabha elections in 2019! When he left, Arjun could not refrain from smiling. "Did you hear that? He is unemployed, and he tells me, his former boss, running a successful international business, that I may need him.... I wanted to tell him that he may need me."

On one occasion, I asked Guddu Bhaia (Ravi’s boss) about Ravi's political career prospects. He looked at me, puzzled. "What do you mean, the computer boy?" He smiled. "He is a Kumar (traditional caste of potters). How many Kumars do we have in town and in the constituency? Maximum 6,000 people.... He does not stand a chance of getting a ticket in this part of the state. Plus, he is not strong (tej). No money. What kind of possibility of winning an 
election will he have? None!" He laughed again. "But he is a nice boy, devoted. And we need him for the computers...."

\section{Shiv Singh (western Uttar Pradesh)}

Shiv is twenty-seven years old. He is also one of the young men who keeps himself close to Guddu Bhaia and the local SP leadership. Unlike Ravi, he belongs to "the right caste" - he is a Thakur like his boss. Also unlike Ravi, he seems to be eager to be associated with the "goonda" (criminal) image of the political party. He wears dark shades, usually jeans, colorful and shiny tshirts, and big jewelry. He travels with a powerful motorbike, but he aspires to buy a Pajero- the big four-by-four car, which is currently very much in fashion among political leaders and dabangs in provincial Uttar Pradesh. He also plans to contest elections in 2022. He will be ready by then. He concedes, however, that he is conscious that in order to get power he needs money. His family is by no means wealthy. They have a few plots of land, nothing more. Also, they are not very supportive of his "career path" and his father thinks that he is just "time passing" and going around with the wrong people. But, along with some of his friends, he discovered that politics might indirectly provide him with some easy cash. Arjun and his friends (all Rajput men in their twenties) improvised careers as extortionists by cashing in on the "goonda" reputation of the Samajwadi Party, and its Rajput face, the famous mafia-don Raja Bhaia. They are not the only ones. In the district under study, a variety of people (from businessmen to unemployed people to aspirant leaders) associated themselves with the Samajwadi Party—which was popularly known as a "goonda [criminal] party and a reputable criminal enterprise" - and use this connection to start their careers as enforcers or in the business of protection. 
In many instances, the names of the SP and Raja Bhaia may indeed successfully function as tokens of protection and deterrents, as they communicate a certain reputation. As scholars of the mafia have elaborated, reputation is of key importance in the business of protection and enforcement. So what we witness is a multiplication of predatory centers of power, in competition with each other, which is producing a sense of chaos and anarchy in the town and state: a "Mafia Raj" (Martin and Michelutti 2017). In this environment, people are aware that they can be tricked. They no longer know whom they have to pay "to get things done" or to beat someone up. It is in this chaotic environment that Shiv and his crew tried to convert the violent reputation of the SP and their Rajput networks into money, although without much success.

To elaborate, in early 2013, Shiv started to advertise his enforcement services to the shopkeepers and small businessmen of the local bazaar who are often also money lenders. As such, from time to time, they need muscle to recover loans or to get protected by local goons, who ask for money in return for their services. Arjun said that the business mainly involved intimidation. They did not use weapons and thought that they could just get away by enacting threats (dhamkhana). However, as soon as one of the clients rebelled, Shiv and his crew backed off and ran away. Their business lasted only a few months. In order to be effective, violent reputations need to be reconfirmed with real and visible acts of violence from time to time. Arjun and his friends did not have the capacity, the means, and most importantly, the willingness to do it. "I am not a criminal," he said.

Additionally, Shiv also engaged in money lending but had troubles in recovering his own loans. We discovered from two established enforcers from the local akhara (wrestling arena) that Arjun had asked them to recover one of his loans. As the story goes, Arjun needed to recover Rs 50,000. His men, however, did not want to go to muscle up the "client" because the client's wife 
was known to be a very smart lady. Going to their house may have meant that they could end up in jail with a fake rape charge. Furthermore, they found out that the cousin of "the smart lady" was a member of the local oil mafia: "Those people do not joke, they have pistols, [and] they kill you. They have full political protection." Basically, Shiv realized that he did not have the contacts to get out of a potentially dangerous situation, and did not want to risk his life in trying to impose his will by violence.

\section{BECOMING AN ENFORCER (DABAG OR MASTAN): TWO STORIES}

\section{Khaled (Sylhet)}

Khaled is in his mid-thirties; he is married with young children. After Khaled passed his SSC (high school) examinations, he decided to further his education. He attended a local college, where he first became involved in party politics. At college and university campuses in Bangladesh, students are attracted to political parties due to their ubiquity, and, more importantly, the "conveniences" (shubidah) they offer (Ruud 2010). At the time of his recruitment, the Bangladesh Nationalist Party (BNP — center-right) was the ruling party. Consequently, the student wing of the party, the Bangladeshi Jatiyatabadi Dal (BJD), was in a very powerful position on campus. Ruling party groups are offered subsidized quotas in residence halls, are given cash grants to organize student events, and are permitted to offer "protection" to surrounding businesses. The activists are mainly young men, who are often armed and potentially violent. Those students who decide to join the group are afforded "benefits" (bebosthan), such as free lodging, subsidized tuition fees, and personal protection. Khaled became an active member of the BJD while at college, organizing and participating in numerous street protests, strikes, and cross-party skirmishes. His enthusiasm and competence 
were promptly recognized by the BNP hierarchy, who promoted him to leadership positions within the BJD contingent at the college. His activism, however, had a disruptive effect on his studies, and Khaled duly failed his Higher Secondary Certificate examinations. Unable to progress to university, Khaled decided to return to the village and try his hand in business. Once back in the village, he remained politically active, competing for and succeeding in winning office as president of the union Jubo Dal (the youth wing of the BNP) — a position he still holds.

Like Ahmed and Tufayl, Khaled also reaps financial rewards from transnational links. Khaled has utilized this flow of capital in various business ventures. He opened a bookshop in Goala Bazaar (a local bazaar town), and bought a minibus and people-carrier for private hire. He has used his money and political influence to forge a formidable reputation in the village; he is widely respected for his industry and intelligence, particularly among the elders. He is wellspoken, respectful, and courteous, although slightly introverted, which succeeds in enhancing his enigmatic presence in public. His impressive resume, wealth, and noble characteristics have enhanced his standing in the public sphere, and recently resulted in him being appointed the youngest-ever president of the Government Primary School—a key position for would-be political careerists. Our informants are keen to point out that Khaled is not as squeaky clean as his public demeanor suggests, however:

Khaled is a former classmate of mine, and I know him very well. He's considered a "big cheese" (boro manush) in the village these days, because he has a lot of money. But his background is modest. People respect that. They respect people who've made money from nothing. He shows his money now — splashing it here and there- but also in the clothes that he wears, even the way he walks. He's ambitious. He wants to go all the way 
to the top. At the top, the most money can be made. The biggest businessmen are the most senior politicians. That's where he wants to get. People think his interests are in social development (somaj-sheba), and he's done a very good job in convincing the elders of this. But I know that it's all bithor-gian (self-centered). It's about being in a position where you can take a "cut" on public funds. The higher the office, the bigger the funds.

In addition to his many political talents, Khaled also possesses an aptitude for violence and intimidation. When agitated, his public speeches can be intense and austere, not shying away from verbal confrontation with opponents, and subtle threats of reprisal, when required. Khaled, however, is not an ostensible mastaan, insofar as he is not well built or athletic; he speaks in a refined manner and is always well groomed. Furthermore, even though he is the bona fide owner of firearms, he seldom displays them in public, or, like most mastaans, boasts of their existence. Instead, he exhibits them when necessary, most often when disputes become untenable. These attributes all combine to create a mysterious, charismatic, and highly pragmatic leader who is widely perceived and touted to reach the summit.

In a similar fashion to Ahmed and Tufayl, Khaled also offers improvised "services" to the villagers. Unlike them, however, he actually can enforce their delivery. At his bookstore in Goala Bazaar and in his home, he holds office for villagers and members of his political party. They approach him for a variety of purposes, including arbitration, provision of loans, and official references. On occasion, he appropriates the use of force (actual or threatened), depending on the case, to deliver "services." It is widely rumored that Khaled wants to compete in the next union elections as a candidate for chairman. His selection as chairman would 
constitute a radical shift in the history of union politics as well as in the wider region.

Traditionally, union heads in Sylhet tend to originate from landed backgrounds. They are usually successful businessmen in some capacity or can boast of an established political career.

In recent years, however, this pattern is being challenged by younger, savvy individuals who rise through the ranks of the two dominant political parties by demonstrating their acumen in business (both licit and illicit), organizing protection syndicates, and mustering a popular following at the local level. Elsewhere, we have argued that this type of leadership has its origins in the ever-burgeoning "muscularity" of student politics in the country-and the urban tactics that are synonymous with it—which is gradually managing to penetrate the country's rural hinterland (Hoque 2014; cf. Ruud 2014). Given these national developments, it may be somewhat unwise to entirely dismiss the scope of Khaled's ambition or, indeed, his potential appointment.

Khaled, then, is the archetypical powerful, self-made man and enforcer-politician. Although he is as yet unelected, in his day-to-day life he displays all the attributes of "real power." Thus far in his early career, he has successfully navigated the formative world of student politics, built up a business empire through criminal entrepreneurship, and ultimately entered the upper echelons of rural politics by exhibiting his skills in performing both sheba (social work) and mastani (criminal work) in an effective way.

\section{Akhilesh Chowdhery (western Uttar Pradesh)}

Akhilesh Chowdhery is in his early thirties like Khaled. He is a Jat, which is the dominant caste of the district. He used to be the chamcha of two of the most powerful old Jat leaders of the area, who groomed him to be the new muscular face of their regional caste party, 
the Rashtriya Lok Dal (RLD), which is known to be the Jats' party in western Uttar Pradesh. Akhilesh was eventually elected president of the Zila Parishad.

Akhilesh's father is a simple village sarpanch and a farmer. He got money by being close to the right centers of power and for his willingness to be a member (and now a leader) in local mafia criminal enterprises. Like Khaled, Akhilesh does not have a muscular physique. He does not look like the "typical" strong, tall Jat young man. On the contrary, he is fairly short and thin, but he possesses a natural authority. He is highly feared by his entourage and by the people working at the District Magistrate (DM) office. The DM is under the scrutiny of the Zila Parishad. Akhilesh told us in a very cocky voice: "The DM is my secretary and I can transfer him when I want.” Even if quite young, Akhilesh has already acquired a reputation for being "cruel" and "ruthless." He does indeed inspire more fear than love.

The following description is about how Akilesh got elected president of the Zila Parishad at such a young age. This conversation helps us to understand what getting power at high levels means in this part of the world. Here is how a prominent local caste leader (teacher, sixty-two years old) narrated the story to us:

These are "public secrets" [he used exactly these words in English]. I can tell you all about it. The previous president (X) was elected Zila Parishad president in 2011. He is also a young Jat, a muscular dabang type of leader. The majority of members who elect the Zila Parishad are Jats. It was then a question of getting the right number of votes and building support across Jat factions or clans. At that time, there was a tussle between the local MP (from RLD) (Y) and the state minister for Rural Development (both very important Jat leaders) (Z). 
The local MP (Y) supported X. Since the Bahujan Samaj Party was in government, many Jat clans supported him. (RLD and BSP had an alliance.) Y's faction had the support of sixteen Zila Parishad members. They were sent to Goa for two weeks before the election to avoid the fact that $\mathrm{Z}$ intimidated or bribed them. $\mathrm{Z}$ was also supported by sixteen Zila Parishad members. He kept them secure (i.e., kidnapped) in a guesthouse.

Five members were however not aligned, and both parties fought for them. Both parties wanted the vote of these five members in order to win the election. Meanwhile RLD people came to know that one of the members (G.R.) took 80 lakhs from $\mathrm{Z}$ to vote for the other faction. He actually was in Goa but his wife took money from Z. The local MP (Y) came to know about this deal and he moved all his "supporters" from Goa to Nepal (his father at the time was the Aviation Minister).

All members came back to town only the day before election. Meanwhile, $\mathrm{Z}$ came to know that G.R. had also taken money from RLD and that he was voting for RLD. The night before the election $\mathrm{Z}$ went to G.R.'s house and beat him up. He destroyed the interior of his house and took his money back. He is still in very bad shape. He is not able to walk without a stick. Go to see him and you will see it with your own eyes. So X got elected as president. After one year the SP government came into power and, of course, they wanted to have an SP president. So the SP started giving money to members to sign a "no confidence" motion.

Finally, some members signed the "no confidence" motion paper. X had to resign from the president post. A committee was formed to run the transition for six months. During these six months a war sparked between the SP and RLD for the president post. RLD decided that they needed a candidate with money and muscle: a dabang. They got on 
board Akhilesh Chowdhery. A very young man (early thirties) who allegedly made a lot of money by running the local oil mafia. He is a proper dabang. He also has good relations with $\mathrm{Z}$ and other important old leaders (all allegedly involved in the oil mafia). So he was a suitable candidate for the president's post. He managed to get a good number of votes and finally got selected as a president. He had to give lots of money to the members in order to get voted....

The "public secret" stopped being so public when we pushed and tried to have more information about the "oil mafia." We could sense that suddenly a more dangerous terrain was touched. "It is best to stay out of it," he suggested. The oil mafia is said to have grown phenomenally over the past thirty years. It has been documented that one thousand liters of oil are stolen yearly. Oil is siphoned off from the main pipeline of India Oil Corporation, which runs from Gujarat to Uttar Pradesh via Rajasthan. Crude oil is stolen from the pipes, adulterated, and sold to both black and official markets (Michelutti et al., forthcoming). Oil syndicates involve the organization of a variety of players: tankers, ration shop owners, civil supplies department officials, the police, and, crucially, politicians. Without political protection, the oil mafia does not exist. Brutal killings of Indian Oil Corporation officers and of government officers have made clear to the locals that the "oil rackets" make "offers that cannot be refused."

\section{CONCLUSIONS}

In this article we show how a great deal of young men (and seldom women) improvise political and "criminal" careers in this part of the world. Our stories show that to become the chamcha of a boss, and to be recognized as part of his or her entourage, is often the first career 
step aspiring bosses take. This involves being seen at politicians' darbars, the panchayat or municipalities meetings, at political rallies, at inaugurations, at weddings, and of course in election campaigns and on Election Day itself. People need to know that one is close to power and able to gain and cultivate it. One has to also stage authority in a variety of ways. For example, looking busy is crucial. This often means being seen with a mobile phone attached to one's ear for long periods - in order to create the effect of busyness (besto manush) and importance (dorkari manush). Thirdly, one must make efforts to get to know as many local people as possible in order to garner a reputation as a concerned servant of the community and a "good person" (balo manoush, sajjan). Finally, one increasingly needs the muscle (or the credibility that one can use muscle) to enforce. Once people have noticed the young jugaadi, he or she must be in a position to offer or impose "services" (sheba, sewa) and protection to the people. It is at this final hurdle that many aspiring bosses fall, but not for want of trying. In the end, only a few "jugaadis" manage to climb the ladder within the local systems of Mafia Raj. In order to advance, they need to acquire and cultivate enforcement skills. These skills are not easy to bluff and improvise. They are not acquired at darbars or at political parties' conventions, but mainly by engaging with criminal entrepreneurship. Ultimately, our stories show qualitatively different forms of jugaad. On the one hand, we have jugaad as a way of getting by, and on the other we have jugaad as a criminal prerequisite to achieve self-determination and dominance. As Pine $(2012,10)$ has marvelously captured in his study on Naples: "The art of making do is a speculative performance, the staging of a better life. Enacting it requires creative tactics for seizing opportunities and negotiating risks. Excessive speculation however can lead to violent determinations: the ad hoc art of making do has the potential to transmogrify into organized crime." 
If in Naples the figure of the self-realized sovereign is ultimately incarnated in the figure of a camorrista (a clan affiliate), in western Uttar Pradesh and Sylhet the self-realized sovereign is incarnated in the figures of the mastan and dabang who belong to organized systems of criminal entrepreneurship. In both settings, organized systems of crime work through contacts that perpetually rope in young men to work for companies or groups linked to local party machines (Hoque 2014; Martin and Michelutti 2017). The successful dabang or mastan carves out for himself or herself monopolies over coercion and businesses in particular territories.

These systems are not static or by any means centrally and hierarchically organized. They are fluctuating systems, highly volatile and in perpetual transformation. However, this does not mean that they should be considered just disorganized and episodic acts of sovereignty. This approach would underestimate the organized systems of criminality and systems of "democratic" domination, which dabang and mastan performances produce, reproduce, and sustain (see Michelutti et al., forthcoming). It should be emphasized that organized mafia types of goondagardi are essentially directed to obtain profit. Goondagardi is not a social service that operates for the benefit of all (the entire population in one territory or also particular castes or communities), but rather a "service" that often acts against society as a whole for the benefit of the few. In spite of this, it is a world that cannot be painted with monochrome terms such as victims, villains, or heroes. It is a world in which it is difficult to establish who is the victim and who is the perpetrator. It is a world in which individuals can engage in both dominant and subaltern practices at the same time. These are also systems that live in perfect "symbiosis with a myriad of protectors, accomplices, debtors of all kinds, informers, and people from all strata of society, who have been paid, bribed, intimidated or blackmail" (Falcone and Padovani 1993, 81). This is the terrain where criminal political entrepreneurship grows and, once established, is often 
"retrospectively" accepted by the community and, crucially, receives formal democratic legitimatization.

\section{Acknowledgments}

Research for this article was conducted within the framework of the research program "Democratic Cultures" (http://www.ucl.ac.uk/democratic-cultures), which is directed by Lucia Michelutti. The project was funded by ERC-AISMA/284080 and ESRC-ES/Io36702/1. We thank all the team members and Jonathan Spencer for their comments and suggestions on previous drafts. The authors share equal responsibility for the article and are listed in alphabetical order.

\section{List of References}

ANAND, NIKHIL. 2015. "Leaky States: Water Audits, Ignorance, and the Politics of Infrastructure." Public Culture 27(2):305-30.

Arias, ENRIQUe D., and DANIEL M. GoldSTEIN, eds. 2010. Violent Democracies in Latin America. Durham, N.C.: Duke University Press.

BAyARt, JeAn-Francois, StePhen Ellis, and BEATRICE HibOU. 1999. The Criminalization of the State in Africa. Oxford: James Currey.

BERENSCHOt, WARD. 2011. "Political Fixers and the Rise of Hindu Nationalism in Gujarat, India: Lubricating a Patronage Democracy." South Asia: Journal of South Asian Studies 34(3):382-401.

BIRTChNell, Thomas. 2011. “Jugaad as Systemic Risk and Disruptive Innovation in India.” Contemporary South Asia 19(4):357-72. 
Briquet, JeAN-Louis, and GILlES FAVAREL-GARRIGUES. 2010. Organized Crime and States: The Hidden Face of Politics. New York: Palgrave Macmillan.

Chandra, Kanchan. 2004. Why Ethnic Parties Succeed. Cambridge: Cambridge University Press.

2015. "The New Indian State. The Relocation of Patronage in the Post-Liberalisation Economy." Economic and Political Weekly 1 (41):46-58.

CHATTARAJ, SHAHANA. 2018. Jugaad. The Global Informality Project. http://informality.com/wiki/index.php?title=Jugaad (India)\&action=edit (accessed July 10 2018).

Comaroff, JeAn, and John L. Comaroff, eds. 2006. Law and Disorder in the Postcolony. Chicago: University of Chicago Press.

- 2016. The Truth about Crime: Sovereignty, Knowledge, Social Order. Chicago: Chicago University Press.

Das, Veena, and Deborah PoOLE, eds. 2004. Anthropology in the Margins of the State. New Delhi: Oxford University Press.

Falcone, Giovanni, and Marcel PAdOVAni. 1993. Men of Honour: The Truth about the Mafia. London: Time Warner.

Gambetta, Diego. 1993. The Sicilian Mafia: The Business of Private Protection. Cambridge, Mass.: Harvard University Press.

GARBIN, DAVID. 2002. "Bideshi Taka: Argent, Migration et Politiques Transationales Entre Banglatown (Londres) et Sylhet (Bangladesh)" [Bideshi Taka: Money, Migration and Transnational Policies between Banglatown (London) and Sylhet (Bangladesh)]. Journal des Anthropologues 90-91:55-77. 
GARDNER, KATY. 1995. Global Migrants, Local Lives: Travel and Transformation in Rural Bangladesh. Oxford: Clarendon Press.

GAYer, LAURENT. 2014. Karachi: Ordered Disorder and the Struggle for the City. London: Hurst.

Hansen, ThOMAs Blom. 2001. Wages of violence: Naming and identity in postcolonial Bombay. Princeton, NJ: Princeton University Press.

Hansen, Thomas Blom, and Finn Stepputat, eds. 2005. Sovereign Bodies: Citizens, Migrants, and States in the Postcolonial World. Princeton, N.J.: Princeton University Press.

HANSEn, ThOMAs Blom, and OSKar VerkaAiK. 2009. “Introduction-Urban Charisma: On Everyday Mythologies in the City." Critique of Anthropology 29(1):5-26.

HARPER, TIM, and SUnIL S. AMRITH. 2012. "Sites of Asian Interaction: An Introduction." Modern Asian Studies 46(2):249-57.

HARriss-White, BARbARA. 2003. India Working: Essays on Society and Economy. Cambridge: Cambridge University Press.

HoQue, Ashraf. 2014. "The Political Mercenary: The Emergence of the Mastaan in Bangladeshi Politics.” Working paper presented at Democratic Cultures Workshop, Arundel, Sussex.

Humphrey, Caroline. 1999. “Traders, 'Disorder’ and Citizenship Regimes in Provincial Russia." In Uncertain Transition: Ethnographies of Change in the Postsocialist World, eds. Michael Burawoy and Katherine Verdery, 19-52. Lanham, Md.: Rowman \& Littlefield.

JAFFE, RIVKE. 2012. 2013. "The Hybrid State: Crime and Citizenship in Urban Jamaica." American Ethnologist 40(4):734-48. 
JAFFrelot, Christophe. 2002. "Indian Democracy: The Rule of Law on Trial.” India Review 1(1):77-121.

Jalal, AYesha. 1995. Democracy and Authoritarianism in South Asia: A Comparative and Historical Perspective. Cambridge: Cambridge University Press.

JAUREGUI, BEATRICE. 2014. "Provisional Agency in India: Jugaad and Legitimation of Corruption." American Ethnologist 41(1):76-91.

JefFrey, Craig. 2010. Timepass: Youth, Class, and the Politics of Waiting in India. Stanford, Calif.: Stanford University Press.

JEFFREy, CRAIG, JEFFERY, PATRICIA, and Roger JEFFERY. 2008. Degrees Without Freedom? Education, Masculinities, and Unemployment in North India. Stanford, Calif.: Stanford University Press.

Jones, GARETH A.. and DenNis RodGers, eds. 2009. Youth Violence in Latin America: Gangs and Juvenile Justice in Perspective. New York: Palgrave Macmillan.

MANOR, JAMES. 2000. "Small-Time Political Fixers in India's States: 'Towel over Armpit."” Asian Survey 40(5):816-35.

Martin, NiCOLAS, and LuCIA MiCHELUTTI. 2017. "Protection Rackets and Party Machines: Comparative Ethnographies of 'Mafia Raj' in North India.” Asian Journal of Social Science 45(6):692-722.

Michelutti, LuCia. 2008. The Vernacularisation of Democracy: Politics, Caste, and Religion in India. New Delhi: Routledge.

—. 2010. "Wrestling with (Body) Politics: Understanding 'Goonda' Political Styles in North India.” In Power and Influence in India: Bosses, Lords and Captains, eds. Pamela Price and Arild Engelsen Ruud, 44-69. New Delhi: Routledge. 
_ 2014. "Kingship without Kings in Northern India." In Patronage as Politics in South Asia, ed. Anastasia Piliavsky, 283-302. New Delhi: Cambridge University Press.

Michelutti, Lucia, Ashraf Hoque, Nicolas Martin, David Picherit, Paul Rollier, Arild Engelsen RuUd, and Clarinda StiLl. Forthcoming. Mafia Raj: The Rule of Bosses in South Asia. Stanford, Calif.: Stanford University Press.

PARDO, ITALO. 1996. Managing Existence in Naples: Morality, Action, and Structure. Cambridge: Cambridge University Press.

Parnell, Philip C., and StePhanie C. KAne, eds. 2003. Crime's Power: Anthropologists and the Ethnography of Crime. New York: Palgrave Macmillan.

Piliavsky, A. 2014. “Introduction.” In Patronage as Politics in South Asia, edited by A. Piliavsky. Cambridge: Cambridge University Press, 1-39.

Pine, JASON. 2012. The Art of Making Do in Naples. Minneapolis: University of Minnesota Press.

RAFAel, Vicente L., ed. 1999. Figures of Criminality in Indonesia, the Philippines, and Colonial Vietnam. Ithaca, N.Y.: Southeast Asia Program Publications, Cornell University.

RAO, S. and S. DUBE, eds. 2013. Crime through Times. Delhi: Oxford University Press.

REDDY, G. RAM, and G. HARAgOPAL. 1985. "The Pyraveekar: 'The Fixer' in Rural India.” Asian Survey 25(11):1148-62.

RoItMan, JANET L. 2004. Fiscal Disobedience: An Anthropology of Economic Regulation in Central Africa. Princeton, N.J.: Princeton University Press.

RuUd, ARILd Engelsen. 2001. "Talking Dirty About Politics: A View from a Bengali Village.” In The Everyday State and Society in Modern India, eds. Chris J. Fuller and Veronique Benei, 115-36. London: Hurst \& Company. 
— 2010. "To Create a Crowd: Student Leaders in Dhaka." In Power and Influence in

India: Bosses, Lords and Captains, eds. Pamela Price and Arild Engelsen Ruud, 70-95.

London: Routledge.

—. 2014. "The Political Bully in Bangladesh.” In Patronage as Politics in South Asia, ed.

Anastasia Piliavsky, 303-25. New Delhi: Cambridge University Press.

SANCHEZ, ANDREW. 2016. Criminal Capital: Violence, Corruption, and Class in Industrial

India. New Delhi: Routledge.

SCHNEIDER, JANE, and Peter SCHNEIDER. 2008. "The Anthropology of Crime and

Criminalization." Annual Review of Anthropology 37:351-73.

Sen, A. 2007. "Everyday and Extraordinary Violence: Women Vigilantes and Raw Justice in the

Bombay Slums." In Global Vigilantes: Anthropological Perspectives on Violence and

Vigilantism, edited by P. David and A. Sen, 69- 92. London: Hurst.

Sharan, Prabhat. 2012. “The New Mafia Raj.” Deccan Herald, March 17.

http://www.deccanherald.com/content/235260/mafia-raj.html (accessed July 8, 2018).

SiDEL, JoHn. 2004. "Bossism in the Philippines, Thailand and Indonesia: Towards an Alternative Framework for the Study of Local Strongmen." In Politicising Democracy: The New Local Politics of Democratisation, eds. John Harriss, Kristian Stokke, and Olle Tornquist, 51-74. Basingstoke: Palgrave Macmillan.

Simone, A. M. 2004. For the City Yet to Come: Changing African Life in Four Cities. Durham, N.C.: Duke University Press.

Spencer, Jonathan. 2007. Anthropology, Politics, and the State: Democracy and Violence in South Asia. Cambridge: Cambridge University Press.

STANDING, ANDRÉ. 2003. "The Social Contradictions of Organised Crime on the Cape Flats." ISS Paper 74. Pretoria: Institute for Security Studies. 
Vaishnav, Milan. When Crime Pays: Money and Muscle in Indian Politics. New Haven, CT: Yale University Press.

VAN SCHENDEL, WILlEM. 2009. A History of Bangladesh. New York: Cambridge University Press.

VAn SCHENDEL, WILLEM, and ItTy ABRAHAM, eds. 2005. Illicit Flows and Criminal Things: States, Borders, and the Other Side of Globalization. Bloomington: Indiana University Press.

VARESE, Federico. 2001. The Russian Mafia: Private Protection in a New Market Economy. Oxford: Oxford University Press.

VARMA, PAVAN K. 2004. Being Indian: Inside the Real India. Delhi: Arrow.

VolKOV, VADIM. 2002. Violent Entrepreneurs: The Use of Force in the Making of Russian Capitalism. Cornell, N.Y.: Cornell University Press.

WiLkinson, SteVen. 2004. Votes and Violence: Electoral Competition and Ethnic Riots in India. Cambridge: Cambridge University Press.

WiTSOE, JEFFREY. 2009. “Territorial Democracy: Caste, Dominance and Electoral Practice in Postcolonial India.” Political and Legal Anthropology Review 32(1):64-83.

${ }^{1}$ This research project explored the overlap between criminal cultures and politics across India, Bangladesh, and Pakistan. Data were collected by direct observation, conversations, and interviews in a district in western Uttar Pradesh (North India) and in Sylhet (Bangladesh) during twelve months' fieldwork between March 2012 and June 2015. Throughout the text we omitted names and/or used pseudonymous and obscured places.

${ }^{2}$ An emerging literature documents the overlap between crime and politics in South Asia (e.g., Gayer 2014; Hansen and Verkaaik 2009; Jaffrelot 2002; Michelutti 2008; Ruud 2014; Sanchez 
2016; Vaishnav 2017). On the concept of "Mafia Raj" and its variety of ethnographic manifestations, see Michelutti et al. (forthcoming).

${ }^{3}$ For a recent overview of this literature, see the edited volume by Rao and Dube (2013).

${ }^{4}$ For anthropological insights on bossism and mafias: in Africa, see Bayart, Ellis, and Hibou (1999), Roitman (2004, and Standing (2003); for Russia, see Humphrey (1999), Varese (2001), and Volkov (2002); for East and Southeast Asia, see Rafael (1999) and Sidel (2004); for Latin America, see Arias and Goldstein (2010) and Jones and Rodgers (2009); and for the Mediterranean, see Pine (2012).

${ }^{5}$ This ethnographic insight is further substantialized by the discussion of seven case studies (across North and South India, Pakistan, and Bangladesh) in Michelutti et al. (forthcoming). ${ }^{6}$ Traditionally the term darbar was used to refer to any formal court gathering where the king/raja/maharaja was present. Today it is often used to refer to the daily open meetings in which the local politicians/bosses meet the public.

${ }^{7}$ A "Londoni' is someone of Bangladeshi origin was resides in the United Kingdom. Sylhet is the province of Bangladesh where the overwhelming majority of British Bangladeshis originate. ${ }^{8}$ On whistleblowers' killings and the role of mafias in contemporary India, see Sharan (2012). 